Bangladesh J. Plant Taxon. 25(2): 135-148, 2018 (December)

(C) 2018 Bangladesh Association of Plant Taxonomists

\title{
A COMPARATIVE STUDY OF ACHENE MORPHOLOGY IN KOREAN POLYGONACEAE
}

\author{
Min-Jung Kong, Jun-Ho Song ${ }^{1}$, Beom-Cheol An, Sung-Won Son ${ }^{2}$,

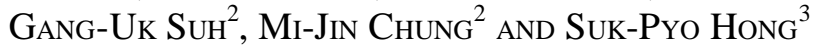 \\ Laboratory of Plant Systematics, Department of Biology, Kyung Hee University, \\ Seoul 02447, South Korea
}

Keywords: Achene surface; Fruit morphology; Micromorphology; Polygonoideae; SEM.

\begin{abstract}
A comparative macro- and micromorphological study was conducted on achenes of Korean Polygonaceae comprising 45 taxa under 10 genera using a Stereo-microscope (SM) and Scanning Electron Microscope (SEM) to evaluate the taxonomical relevance of achene morphological characteristics. The achene shape is lenticular, biconvex, trigonous, or spheroidal. The largest achenes are found in Fagopyrum esculentum Moench (5.80$6.70 \times 3.90-4.40 \mathrm{~mm})$ and Rheum rhabarbarum L. $(5.00-6.50 \times 4.00-5.20 \mathrm{~mm})$, and the smallest is found in Rumex maritimus L. $(1.17-1.41 \times 0.60-0.84 \mathrm{~mm})$. Three types of embryo shape (curved, straight, and folded) and two types of embryo position (plane and parietal) can be distinguished. Most taxa have a curved embryo shape with plane position. Four types of surface patterns (smooth, papillae, tuberculate, or small pits) are observed. The surface sculpture or embryo type is rather consistent at the generic or tribal level, and the comprehensive consideration of achene characteristics is also useful at the species level. The achene morphology is described in detail, compared, and illustrated. The taxonomic significance of the achene morphology is discussed.
\end{abstract}

\section{Introduction}

Polygonaceae Juss. consists of ca. 1,200 species in 48 genera and has a worldwide distribution (Freeman and Reveal, 2005). The family Polygonaceae is usually divided into subfamilies Eriogonoideae Arnott and Polygonoideae Eaton (Freeman and Reveal, 2005), and the subfamily Symmerioideae Meisn. was suggested based on recent molecular phylogeny with number of stamens and pyramidal achene (Brandbyge, 1993; Sanchez et al., 2011). The Polygonoideae has been characterized by herb or sub-shrubs, the presence of ochreae and swollen nodes, flowers subtended by bracteoles but not enclosed in involucres, and cosmopolitan distribution (Haraldson, 1978; Freeman and Reveal, 2005; Sanchez et al., 2011). The subfamily is also consistently confirmed by molecular sequence data (Sanchez et al., 2009, 2011).

However, the taxonomic circumstance of intra-subfamily in Polygonoideae (e.g., tribal, generic, or sectional level) have been controversial, and new tribal compositions were suggested according to recent molecular phylogenetic studies (Freeman and Reveal, 2005; Sanchez et al., 2009, 2011; Schuster et al., 2015). For example, the proposed taxonomic system by these studies consist of five to seven tribes, such as Calligoneae C.A. Mey, Fagopyreae Yoneak., Oxygoneae T.M. Schust. \& Reveal, Persicarieae Dumort., Polygoneae Rchb., Pteroxygoneae T.M. Schust. \& Reveal and Rumiceae Dumort. (matK, ndhF and $r b c \mathrm{~L}$, Sanchez et al., 2011; ITS, matK and trnL-F,

\footnotetext{
${ }^{1}$ Present address: Herbal Medicine Resources Research Center, Korea Institute of Oriental Medicine, Naju 58245, Korea.

${ }^{2}$ Plant Conservation Division, Korea National Arboretum, Pocheon 11186, Korea.

${ }^{3}$ Corresponding author. Email: sphong@khu.ac.kr
} 
Schuster et al., 2015). The taxonomic composition in the Persicarieae or Polygoneae is also most controversial as large group within Polygonoideae, namely the generic or sectional delimitation of these tribes are constantly changing (Hedberg, 1946; Haraldson, 1978; Brandbyge, 1993; Lamb Frye and Kron, 2003; Li et al., 2003; Park and Hong, 2007; Sanchez et al., 2011). For example, Persicaria was treated into Polygonum s.l. (Li et al., 2003; Zhu et al., 2007), however recent studies suggested that Persicaria is separated as independent genus (Haraldson, 1978; Ronse Decraene et al., 2000; Lamb Frye and Kron, 2003). Aconogonon and Bistorta were merged into Polygonum in some studies ( $\mathrm{Li}$ et al., 2003; Park and Hong, 2007), while Aconogonon and Bistorta were usually recognized as independent genera (Hedberg, 1946; Haraldson, 1978; Freedman and Reveal, 2005). However, a recent molecular study treated Aconogonon as a section of Koenigia (Schuster et al., 2015). Various research approaches have been attempted to clarify the taxonomic positions within the Polygonoideae; thus, a comparative study of the morphological characteristics or re-evaluation of recently suggested taxonomic system is necessary to determine taxonomic delimitation.

The importance of fruit and seed morphology in flowering plants has been recognized for systematic information at various taxonomic levels; furthermore, several recent studies have shown the phylogenetic value of fruit and seed characteristics (Donoghue et al., 2004; Jacobs et al., 2008, 2010; Choi et al., 2012; Song et al., 2015). The description of anatomical features or micromorphology of the achenes of Polygonaceae were often performed, but only these were performed on represented taxa or regional taxa (e.g., Ronse Decraene et al., 2000; Yurteseva, 2001; Hou et al., 2007; Kantachot and Chantaranothai, 2011), or were simply described without any taxonomic implications (Martin, 1946, 1954). The Korean Polygonaceae is known to that consist of 85 taxa (10 genera) which belong to the tribes Fagopyreae, Persicarieae, Polygoneae and Rumiceae (except Calligoneae, Oxygoneae and Pteroxygoneae) within the subfamily Polygonoideae (Chang et al., 2014; Schuster et al., 2015). However, the study of achene morphology in Korean Polygoanceae has been mainly in the form of brief notes or only on sectional or generic level (Kim et al., 2001; Nakayama et al., 2004; Lee et al., 2010), and is still lacking comprehensive discussion. Thus, the present study aims to investigate and provide detailed descriptions of achene macro- and micromorphology in the selected Korean Polygonaceae, and to evaluate the taxonomic or diagnostic importance of fruit morphological features.

\section{Materials and Methods}

The achene morphology of 45 taxa from 10 genera in the Korean Polygonaceae (Table 1) was investigated. The achenes were collected from herbarium specimens of KH and KHUS, and donated from the seed bank of the Korean National Arboretum, Pocheon, South Korea [see Table 1; abbreviations according to Thiers (2018) and continuously updated].

Fully matured fruits were selected and observed under a stereomicroscope (SM; SteREO Discovery.V8; Carl Zeiss Microscopy GmbH, Germany) to confirm their normality and taxon identification. Cross-sections of the achenes were also taken, and examined under a SM. To observe detailed sculpturing patterns of the achenes, dry fruits were rehydrated overnight in the Agepon wetting agent $\left(\right.$ Agepon $\left.{ }^{\circledR}: \mathrm{DW}=1: 200\right)$, and fresh fruits were fixed in FAA (formaldehide: acetic acid: alcohol) for $48 \mathrm{~h}$, and stored in $70 \%$ ethanol. Prepared achenes were dehydrated through an ethanol series (in 50\%, 70\%, $90 \%$, and $95 \%$ ethanol for 10 min each and in absolute ethanol for about $20 \mathrm{~min}$ ) and then replaced ethanol with carbon dioxide for critical point drying 
Table 1. Voucher specimens of the Korean Polygonaceae that are examined in the present study (Some taxa have only seed bank management number).

\begin{tabular}{|c|c|}
\hline Taxon & Voucher specimens \\
\hline \multicolumn{2}{|l|}{ Aconogonon (Meisn.) Rchb. } \\
\hline A. alpinum (All.) Schur & $\begin{array}{l}\text { Korea, Chungcheongnam-do, Oct.2002, G.W. Seo and J.Y.Kim } \\
\text { (KH-154) }\end{array}$ \\
\hline $\begin{array}{l}\text { A. divaricatum (L.) Nakai ex T. Mori } \\
\text { Bistorta (L.) Scop. }\end{array}$ & Korea, Gyunggi-do, Oct.2004, J.Y. Kim (KH-L1455) \\
\hline $\begin{array}{l}\text { B. manshuriensis (Petrov ex Kom.) Kom. } \\
\text { Fagopyrum Mill. }\end{array}$ & Korea, Gyunggi-do, Aug.2006, J.Y. Kim (KH-L2769) \\
\hline F. esculentum Moench & Korea, Is. Jeju, Oct. 2011, S.H. Kang 111024004 (KH) \\
\hline \multicolumn{2}{|l|}{ Persicaria (L.) Mill. } \\
\hline P. chinensis (L.) H. Gross var. chinensis & Korea, 1s, Jeju, Nov. 2012, M.J. Kongs, n. (KHUS) \\
\hline P. dissitiflora (Hemsl.) H. Gross ex T. Mori & $\begin{array}{l}\text { Korea, Gyungsangbuk-do, Sep.2012, S.G. Son and H.W.Choi (KH- } \\
\text { L10091) }\end{array}$ \\
\hline P. filiformis (Thunb.) Nakai & Korea, Gyunggi-do, Sep.2005, J.Y. Kim (KH-L2208) \\
\hline P. hydropiper (L.) Delarbre & Korea, Gyunggi-do, Oct.2002, G.W. Seo and J.Y. Kim (KH-L153) \\
\hline P. japonica (Meisn.) Nakai & Korea, Gyunggi-do, Nov.2004, J.Y. Kim (KH-L1835) \\
\hline P. lapathifolia (L.) Delarbre var. lapathifolia & Korea, Gyunggi-do, Sep.2012, J.Y. Kim (KH-L10035) \\
\hline $\begin{array}{l}\text { P. lapathifolia var. salicifolia (Sibthorp) } \\
\text { Miyabe }\end{array}$ & Korea, Incheon, Nov.2014, S.H. Park et al. (KH-L14267) \\
\hline P. longiseta (Bruijn) Kitag. & Korea, Gyungsangbuk-do, Sep.2004, G.W. Seo et al. (KH-L1329) \\
\hline P. maackiana (Regel) Nakai ex T. Mori & Korea, Gyungsangnam-do, Oct.2012, S.D. Lee (KH-L10050) \\
\hline P. muricata (Meisn.) Nemoto & Korea, Gyunggi-do, Oct.2007, J.Y. Kim (KH-L3238) \\
\hline P. nepalensis (Meisn.) H. Gross & Korea, Gangwon-do, Sep.2011, M.S. Kim et al. (KH-L8969) \\
\hline P. nodosa (Pers.) Opiz & Korea, Gyunggi-do, Nov.2004, J.Y. Kim (KH-L1821) \\
\hline P. orientalis (L.) Spach & Korea, Gyunggi-do, Oct.2003, J.Y. Kim (KH-L798) \\
\hline P. perfoliata (L.) H. Gross & Korea, Gyungsangbuk-do, Aug.2014, G.H. Gang (KH-L13798) \\
\hline P. posumbu (Buch.-Ham. ex D. Don) H.Gross & Korea, Gyunggi-do, Oct.2007, J.Y. Kim (KH-L3309) \\
\hline P. pubescens (Blume) H. Hara & Korea, Gyungsangbuk-do, Oct.2014, G.H. Gang et al. (KH-13817) \\
\hline P. sagittata (L.) H. Gross & Korea, Gyunggi-do, Oct.2006, J.Y. Kim (KH-L2914) \\
\hline P. senticosa (Meisn.) H. Gross & $\begin{array}{l}\text { Korea, Gyungsangbuk-do, Sep.2012, S.G. Son and H.W.Choi (KH- } \\
\text { L10094) }\end{array}$ \\
\hline P. thunbergii (Siebold \& Zucc.) H. Gross & Korea, Gyunggi-do, Oct.2007, J.Y. Kim (KH-L3380) \\
\hline P. tinctoria (Aiton) H. Gross & Korea, Gyunggi-do, Oct.2007, J.Y. Kim (KH-L3236) \\
\hline P. viscofera (Makino) H. Gross & $\begin{array}{l}\text { Korea, Gyungsangbuk-do, Aug. 2012, S. G. Son and H.Y. Choi } \\
\text { (KH-L10095) }\end{array}$ \\
\hline $\begin{array}{l}\text { P. viscosa (Buch.-Ham. ex D. Don) H. Gross } \\
\text { ex T. Mori }\end{array}$ & $\begin{array}{l}\text { Korea, Gyungsangbuk-do, Sep.2012, S.G. Son and H.S.Kwon (KH- } \\
\text { L10096) }\end{array}$ \\
\hline P. vulgaris Webb \& Moq. & Korea, Gyungsangnam-do, Oct.2012, J.S. Kim (KH-L10059) \\
\hline \multicolumn{2}{|l|}{ Fallopia Adanson } \\
\hline F. convolvulus (L.) A. Löve & Korea, Gyunggi-do, Nov.2005, J.Y. Kim (KH-L2618) \\
\hline F. dentatoalata (F. Schmidt) Holub & $\begin{array}{l}\text { Korea, Jeollabuk-do, Sep.2013, G.S. Jung and S.J. Kwon (KH- } \\
\text { L13170) }\end{array}$ \\
\hline F. dumetorum (L.) Holub & Korea, Gyunggi-do, Nov.2005, J.Y. Kim (KH-L2602) \\
\hline F. japonica (Houtt.) Ronse Decr. & Korea, Gyunggi-do, Nov.2005, J.Y. Kim (KH-L2625) \\
\hline F. koreana B.U. Oh \& J.G. Kim & Korea, Chungcheongbuk-do, Oct.2011, G.Y. Lee (KH-L9470) \\
\hline F. sachalinensis (F. Schmidt) Ronse Decr. & $\begin{array}{l}\text { Korea, Is. Ulleung, Gyungsangbuk-do, Oct.2011, M.S.Kim et al. } \\
\text { (KH-L9025) }\end{array}$ \\
\hline
\end{tabular}


Table 1 Contd.

\begin{tabular}{|c|c|}
\hline Taxon & Voucher specimens \\
\hline \multicolumn{2}{|l|}{ Knorringia (Czukav.) Tzvelev } \\
\hline K. sibirica (Laxm.) Tzvelev subsp. sibirica & Korea, Incheon, Sep.2006, S.H.Park $61732(\mathrm{KH})$ \\
\hline \multicolumn{2}{|l|}{ Polygonum L. } \\
\hline P. aviculare $\mathrm{L}$. & Korea, Gyunggi-do, Oct.2004, J.Y.Kim (KH-L1772) \\
\hline \multicolumn{2}{|l|}{ Oxyria Hill. } \\
\hline O. digyna (L.) Hill & D.P.R.K., Mt. Baekdu, Aug.1997, K.W.Park L-61153 (KH) \\
\hline \multicolumn{2}{|l|}{ Rheum L. } \\
\hline R. rhabarbarum $\mathrm{L}$. & Mongolia, Tariat, Jul.2002, S.H. Park ParkSH23435 (KH); \\
\hline \multicolumn{2}{|l|}{ Rumex L. } \\
\hline R. acetosa $\mathrm{L}$. & Korea, Gyunggi-do, Jun.2007, J.Y. Kim et al. (KH-3324) \\
\hline R. acetosella $\mathrm{L}$. & Korea, Gyunggi-do, Jul.2005, J.Y. Kim (KH-L2135) \\
\hline R. conglomeratus Murray & $\begin{array}{l}\text { Korea, Gyungsangnam-do, Jul.2004, J.M. Jung and M.H.Park (KH- } \\
\text { 1073) }\end{array}$ \\
\hline$R$. crispus L. & $\begin{array}{l}\text { Korea, Gyungsangnam-do, Jul.2004, J.M. Jung and J.Y.Kim (KH- } \\
\text { L1047) }\end{array}$ \\
\hline R. japonicus Houtt. & Korea, Gyunggi-do, Jul.2005, J.Y. Kim (KH-L2126) \\
\hline R. maritimus $\mathrm{L}$. & Korea, Gangwon-do, Sep.2004, J.M. Jung et al. (KH-L1282) \\
\hline R. obtusifolius $\mathrm{L}$. & Korea, Gyunggi-do, Jul.2005, J.Y. Kim (KH-L2127) \\
\hline R. patientia $\mathrm{L}$. & Korea, Chungcheongbuk-do, Jul.2011, E.S. Jeon (KH-L8856) \\
\hline
\end{tabular}

Herbarium acronyms are in accordance with Thiers (2018) [continuously updated]

(CPD, SPI-13200J-AB). All samples for SEM analysis were coated with platinum using an ionsputtering device (E-1045; Hitachi, Tokyo, Japan). Samples were examined under a field emission SEM (FE-SEM; S-4700; Hitachi, Tokyo, Japan) operating at $10 \mathrm{kV}$ with a working distance of 10$13 \mathrm{~mm}$. A total of 10 achenes for CPD were measured using the Magnification 2.0 version software (Orbicule, Leuven, Belgium).

We followed the currently accepted taxonomic treatment for the taxa studied to avoid any taxonomic confusion (Freeman and Reveal, 2005; Sanchez et al., 2011). The terminology for fruits and embryos was mainly adopted from Ball et al. (1962), Brandbyge (1993), and Ronse Decraene et al. (2000).

\section{Results and Discussion}

\section{Achene shape, size, colour, embryo type, and micromorphology}

Shape: The various achene shapes in Korean Polygonaceae were lenticular, biconvex, trigonous, and spheroidal (Table 2; Fig. 1). Most of the taxa studied had trigonous achenes, and the lenticular shape was observed in five taxa within Persicaria ( $P$. hydropiper, $P$. japonica, $P$. lapathifolia var. salicifolia, P. nodosa, and P. orientalis; Table 2; Fig. $1 \mathrm{~F}$ ). Biconvex achenes were found in four taxa (Persicaria filiformis, P. nepalensis, P. tinctoria, and Oxyria digyna; Table 2; Fig. 1C, D \& M), and spheroidal achenes were only observed in Persicaria perfoliata.

The longitudinal-section (L.S.) shapes were found to be elliptic (Fig. 2C, O \& S), elliptic rhomboid (Fig. 2G \& W), ovoid (Fig. 2E, I \& K), broadly ovoid (Fig. 2A, Q \& U), and circular (Fig. 2M). The cross-section (C.S.) shapes were mostly triangular (Fig. 2B, D, F, H, P, T, V \& X), but also sometimes narrowly elliptic (Fig. 2N), elliptic (Fig. 2J), rhombic (Fig. 2R), and triangular- ovoid (Fig. 2L). Most of the taxa studied had a beak (Figs. 1A, B, D, E, F, G, I, J, K, L, N, O, \& 2I). Some had a prominent beak, such as a caudate or cuspidate (Fig. 1B, D, E, F, G, I, \& J), but five taxa had achenes without a beak (e.g., Persicaria filiformis, P. senticosa, P. thunbergii, 
Fallopia dumetorum, Rheum rhababarum, Rumex acetosa, and $R$. acetosella; Fig. 1C \& H). The absence of beak could help to identify some taxa.
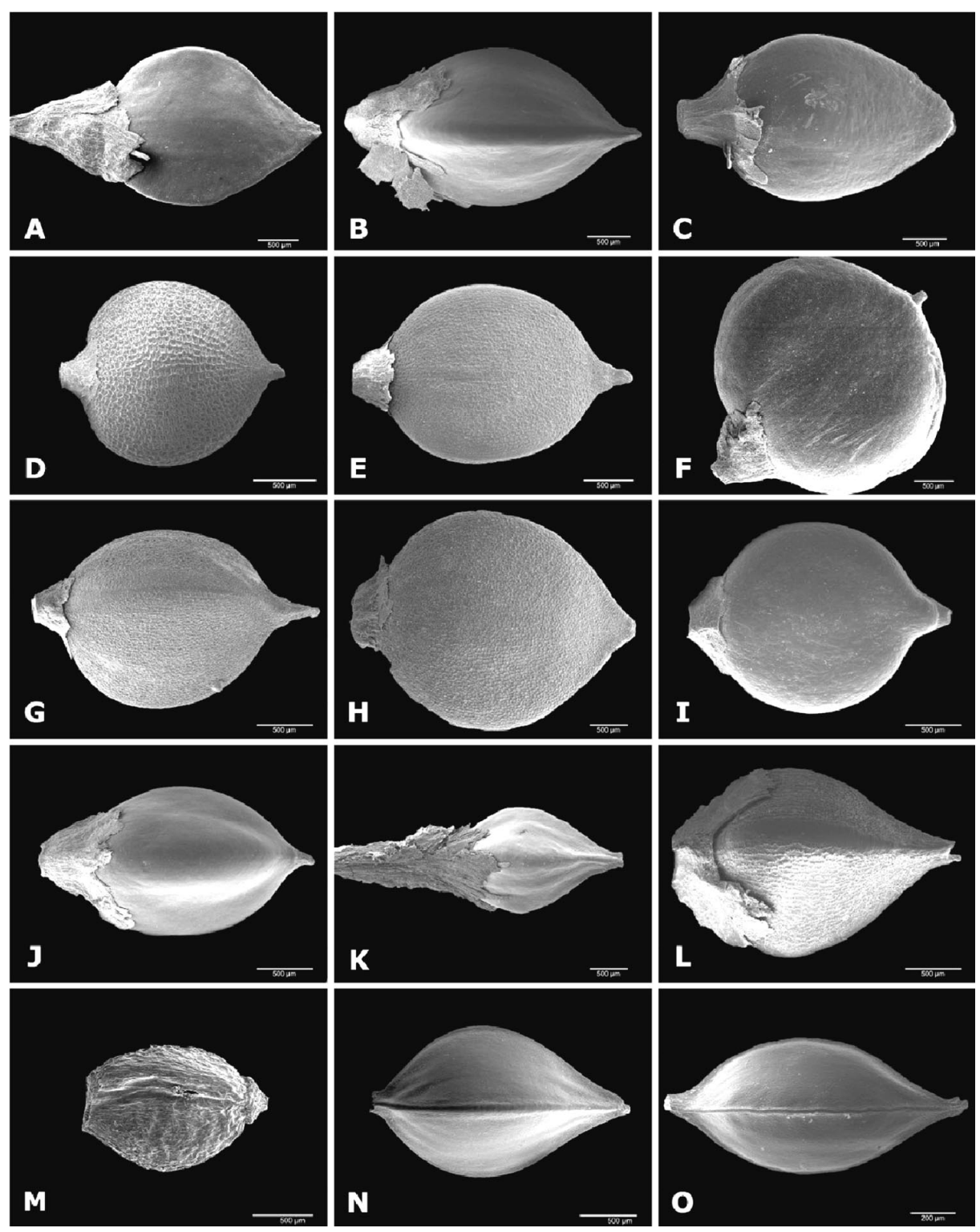

Fig. 1. SEM micrographs of achenes of Polygonaceae in Korea. A. Aconogonon alpinum; B. Bistorta manshuriensis; C. Persicaria filiformis (sect. Tovara); D. Persicaria nepalensis (sect. Cephalophilon); E. Persicaria maackiana (sect. Echinocaluon); F. Persicaria orientalis (sect. Persciaria); G. Persicaria sagittata (sect. Echinocaluon); H. Persicaria thunbergii (sect. Echinocaluon); I. Persicaria nodosa (sect. Persicaria); J. Persicaria pubescens (sect. Persicaria); K. Fallopia sachalinensis; L. Polygonum aviculare; M. Oxyria digyna (beak was broken; see Fig. 2I); N. Rumex obtusifolius; O. Rumex maritimus. 


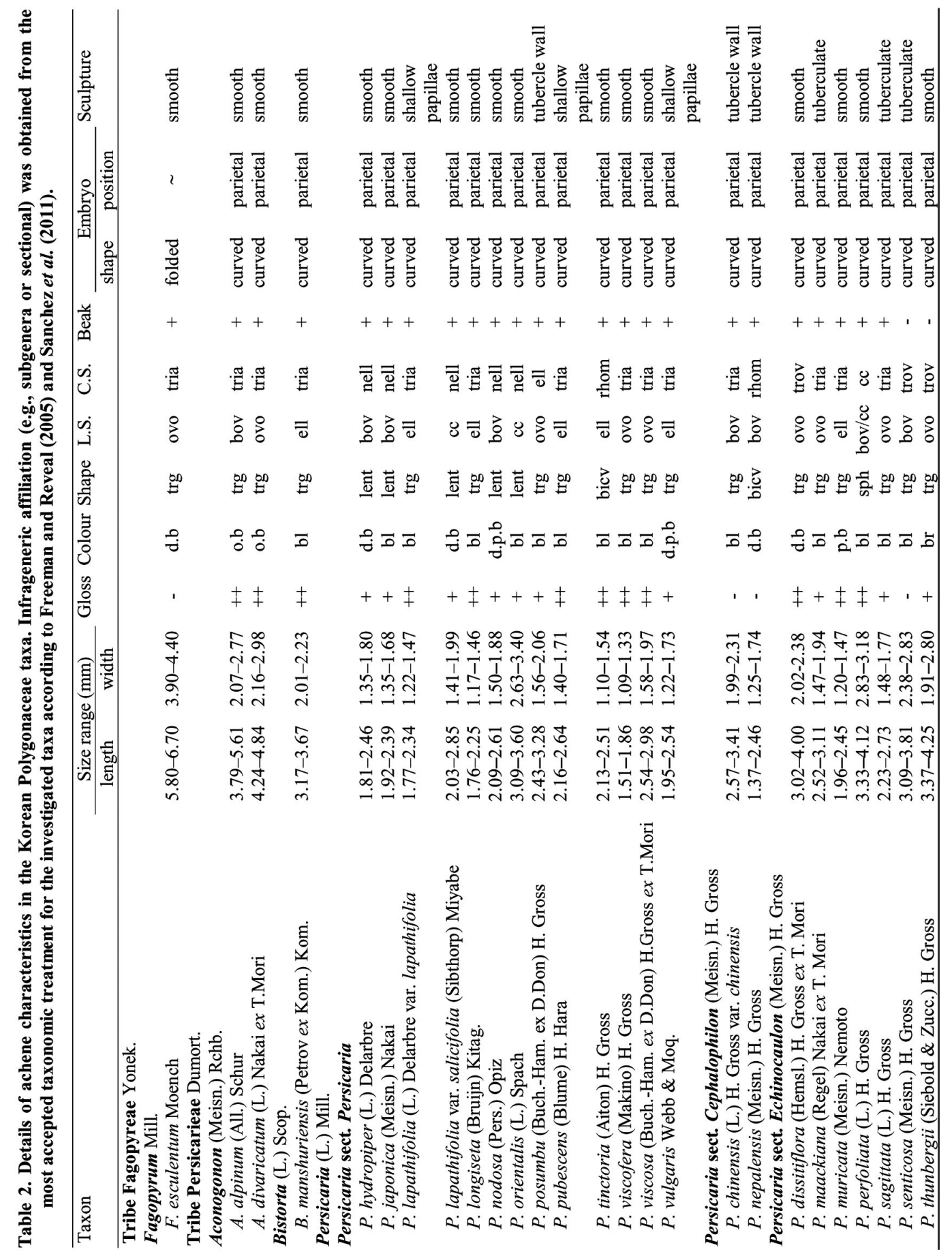




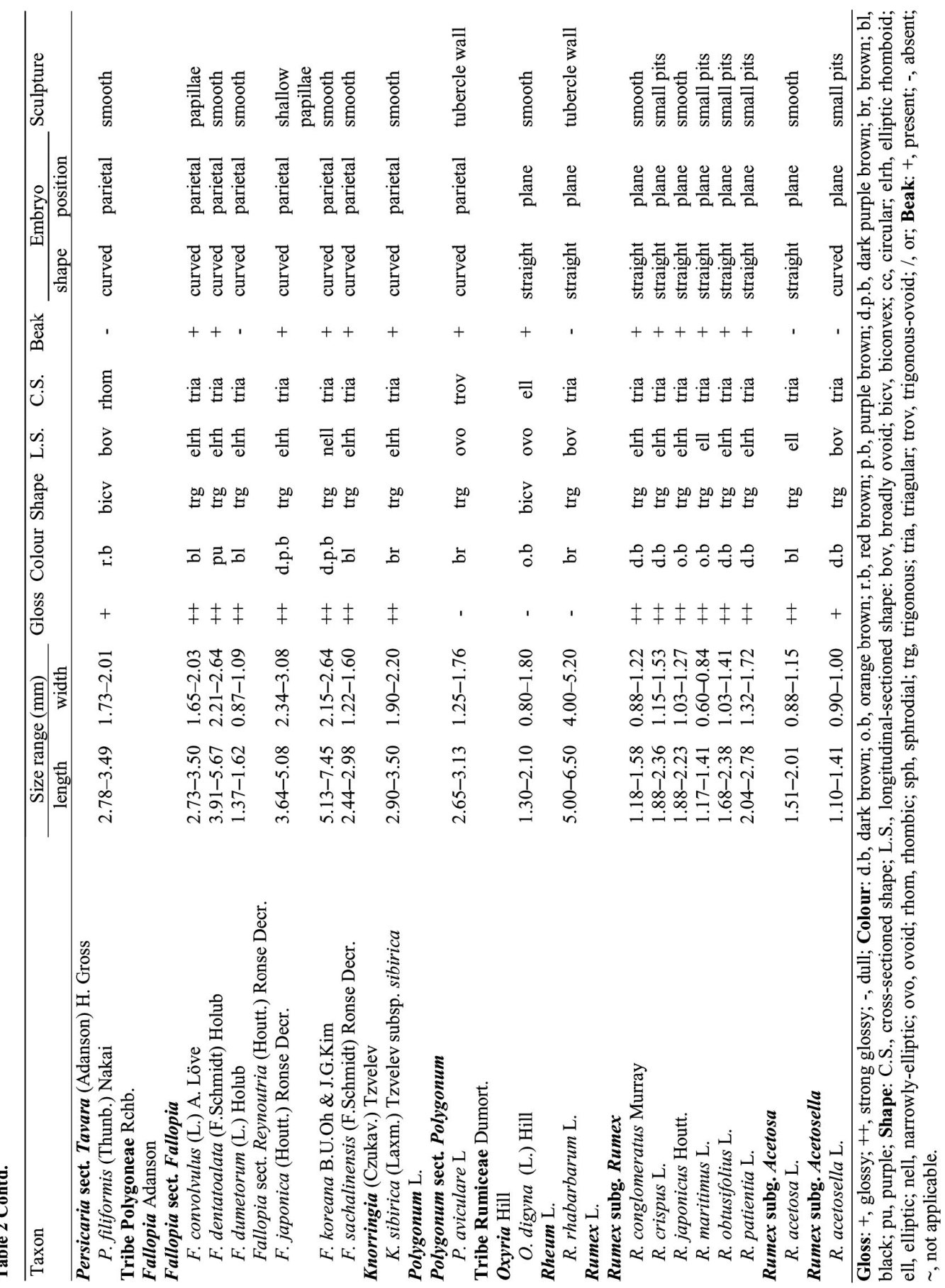



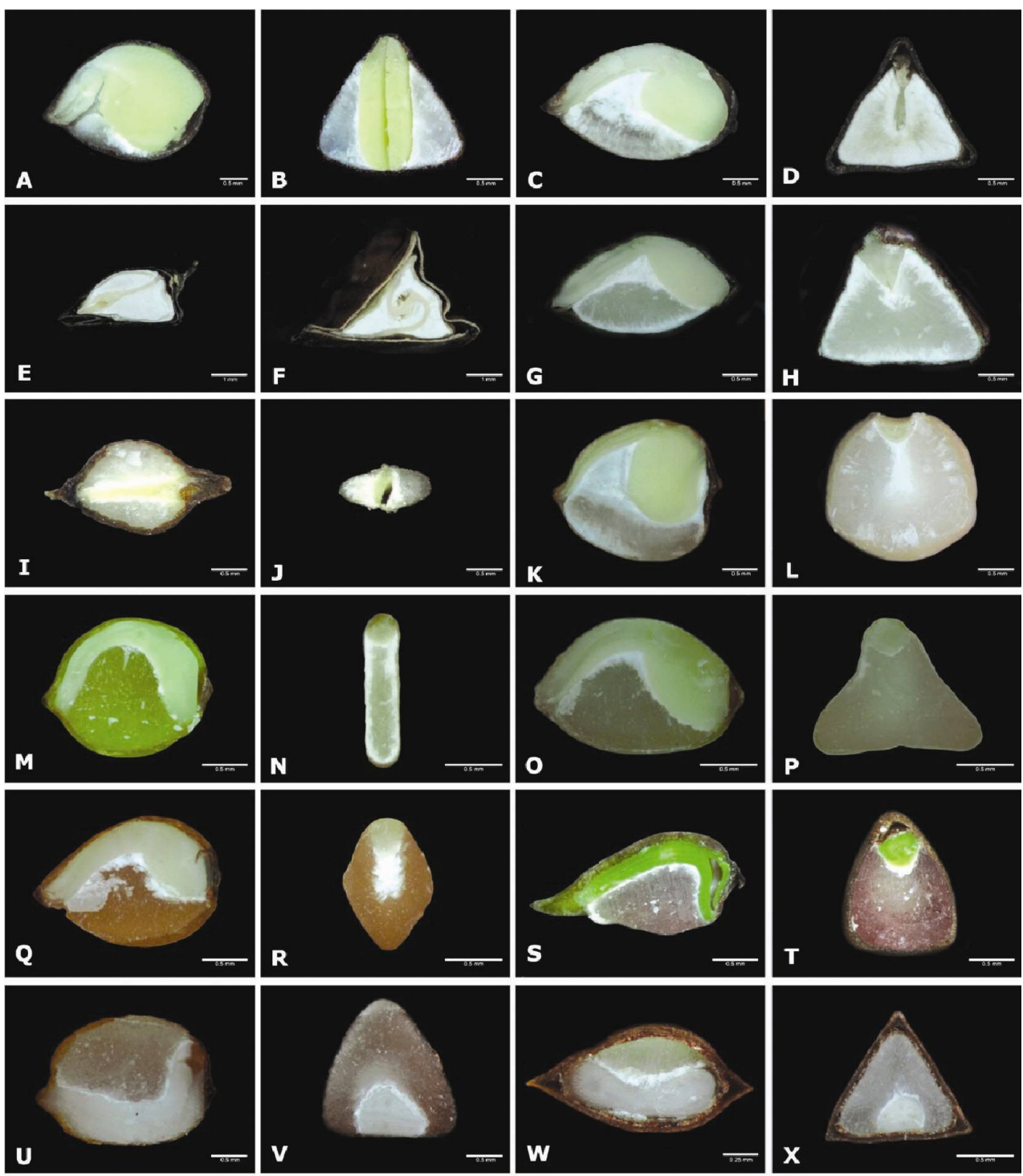

Fig. 2. Cross and longitudinal section of achenes of Polygonaceae in Korea. A, B. Aconogonon alpinum (Type III); C, D. Bistorta manshuriensis (Type III); E, F. Fagopyrum esculentum (Type I); G, H. Fallopia dentatoalata (Type III); I, J. Oxyria digyna (Type II); K, L. Persicaria dissitiflora (sect. Echinocaulon; Type III); M, N. Persicaria lapathifolia var. salicifolia (sect. Persicaria; Type III); O, P. Persicaria pubescens (sect. Persicaria; Type III); Q, R. Persicaria tinctoria (sect. Persicaria; Type III); S, T. Polygonum aviculare (Type III); U, V. Rumex acetosella (Type IV); W, X. Rumex obtusifolius (Type II). A, C, E, G, I, K, M, O, Q, S, U, and W, longitudinal section of achenes; B, D, F, H, J, L, N, P, R, T, V, and X, cross-section of achenes in investigated taxa.

The achene shapes of the taxa studied agreed with the descriptions in earlier studies (Ronse Decraene et al., 2000; Li et al., 2003; Freedman and Reveal, 2005; Lee et al., 2010; Kantachot and Chantaranothai, 2011). According to previous studies, some taxa showed heteromorphy in their 
achene shape; moreover, collecting season has implications on the achene shape (Yurtseva, 2001; Li et al., 2003; Freedman and Reveal, 2005; Kantachot and Chantaranothai, 2011). For example, Persicaria hydropiper has either convex or trigonous achenes (Lee, 2003; Freedman and Reveal, 2005). The achene shape was consistent for each taxon in present study, however, taxonomic application of achene shape could be needed careful application.

Size: The size of achenes ranged from $1.10-7.45 \mathrm{~mm}$ in length and $0.60-5.20 \mathrm{~mm}$ in width (Table 2). The large achenes were found on Fagopyrum esculentum $(5.80-6.70 \times 3.90-4.40 \mathrm{~mm})$ and Rheum rhabarbarum $(5.00-6.50 \times 4.00-5.20 \mathrm{~mm})$, whereas the smallest achenes were found in Rumex maritimus $(1.17-1.41 \times 0.60-0.84 \mathrm{~mm})$. The taxa in Oxyria and Rumex had the small achenes compared to other genera $(1.10-2.78 \times 0.60-1.80 \mathrm{~mm})$. Most taxa, except Fagopyrum esculentum, Rheum rhabarbarum, Rumex acetosella and $R$. maritimus, showed to have similar size ranges of achenes $(1.37-5.67 \times 0.87-3.40 \mathrm{~mm})$. The achene sizes in the taxa studied were also similar to those recorded in earlier studies (Li et al., 2003; Kantachot and Chantaranothai, 2011). The largest or smallest achene sizes could be used to classify to the genus level.

Colour: Fully matured achenes of most of the taxa were brownish to black, and dull or shiny (Table 2); this colour is commonly found in Polygonaceae (Kantachot and Chantaranothai, 2011). The colour of fully matured fruit is usually not an important character to identify genus or species, except for in a few taxa that have odd colours such as grey or greyish green (Kantachot and Chantaranothai, 2011; Sadeghian et al., 2014). Most of the taxa studied had glossy achenes except six examined taxa (Table 2), which had dull achenes (e.g. Fagopyrum esculentum, Oxyria digyna, Persicaria nepalensis, P. senticosa, Polygonum aviculare, and Rheum rhabarbarum). The existence of dull achenes is useful for the identification of the species.

Embryo shape and position: Three embryo shapes were observed in this study, viz. curved, straight, and folded (Table 2; Fig. 2). Most taxa studied had curved embryos (e.g. Aconogonon, Bistorta, Fagopyrum, Fallopia, Knorringia, Persicaria, and Polygonum; Fig. 2A, C, G, K, M, O, Q, S \& U). While Oxyria, Rheum, and Rumex (except $R$. acetosella) had straight embryos (Fig. 2I $\&$ W), and folded embryos were only observed in Fagopyrum (Fig. 2E \& F). The embryo shapes of the taxa studied were similar to those in previously published data (Martin, 1946; Brandbyge, 1993; Freedman and Reveal, 2005; Sanchez et al., 2011). In the present study, all taxa studied had one shape of embryo; however, embryos of Rumiceae were observed to be curved or straight (Freedman and Reveal, 2005). In this study, Rumex acetocella of the Rumex subg. Acetosella had a different shape from other Rumiceae taxa. Additionally, two types of embryo position (plane and parietal) were observed (Table 2; Fig. 2). Most of the taxa had aparietal position (Fig. 2B, D, H, J, L, N, P, R \& T), while Oxyria, Rheum, and Rumex, which belong to the tribe Rumiceae, had a plane-positioned embryo (Fig. 2V \& X).

The embryos can be divided into four types based on shape and position: Type I - folded embryo (Fagopyrum - Fagopyreae); Type II - straight embryo with plane position (Oxyria, Rheum, and Rumex - Rumiceae); Type III - curved embryo with parietal position (Aconogonon, Bistorta, Persicaria, Fallopia, Knorringia, and Polygonum - Persicarieae and Polygoneae); Type IV-curved embryo with plane position (Rumex acetosella). The types are congruent with the delimitation of suggested tribes (Sanchez et al., 2011; Fig. 4). For example, the Type I embryo, which is an unusual type in Polygonoideae, was found only in Fagopyrum. This genus which was separated into the tribe Fagopyreae according to the recent taxonomic system (Sanchez et al., 2011), and its embryo type could be considered to be an apomorphy (Fig. 4). The Persicarieae and Polygoneae both show Type III embryos, which could be assumed to be a parallelism of characteristics when compared with current phylogenetic studies (Fig. 4). The tribe Rumiceae is strongly supported by embryo position; however, embryo shape was varied at generic level. 
Achene micromorphology: Four types of achene surfaces were recognized: smooth, papillae, tuberculate, and small pits (Table 2; Fig. 3). Most taxa had smooth to rugose surfaces without appendages (Fig. 3A, B, H \& M). These types had remarkable anticlinal cell walls, generally undulated, and of these, Fagopyrum esculentum was characterized by longitudinal grooves on the achene surface (Fig. 3C).

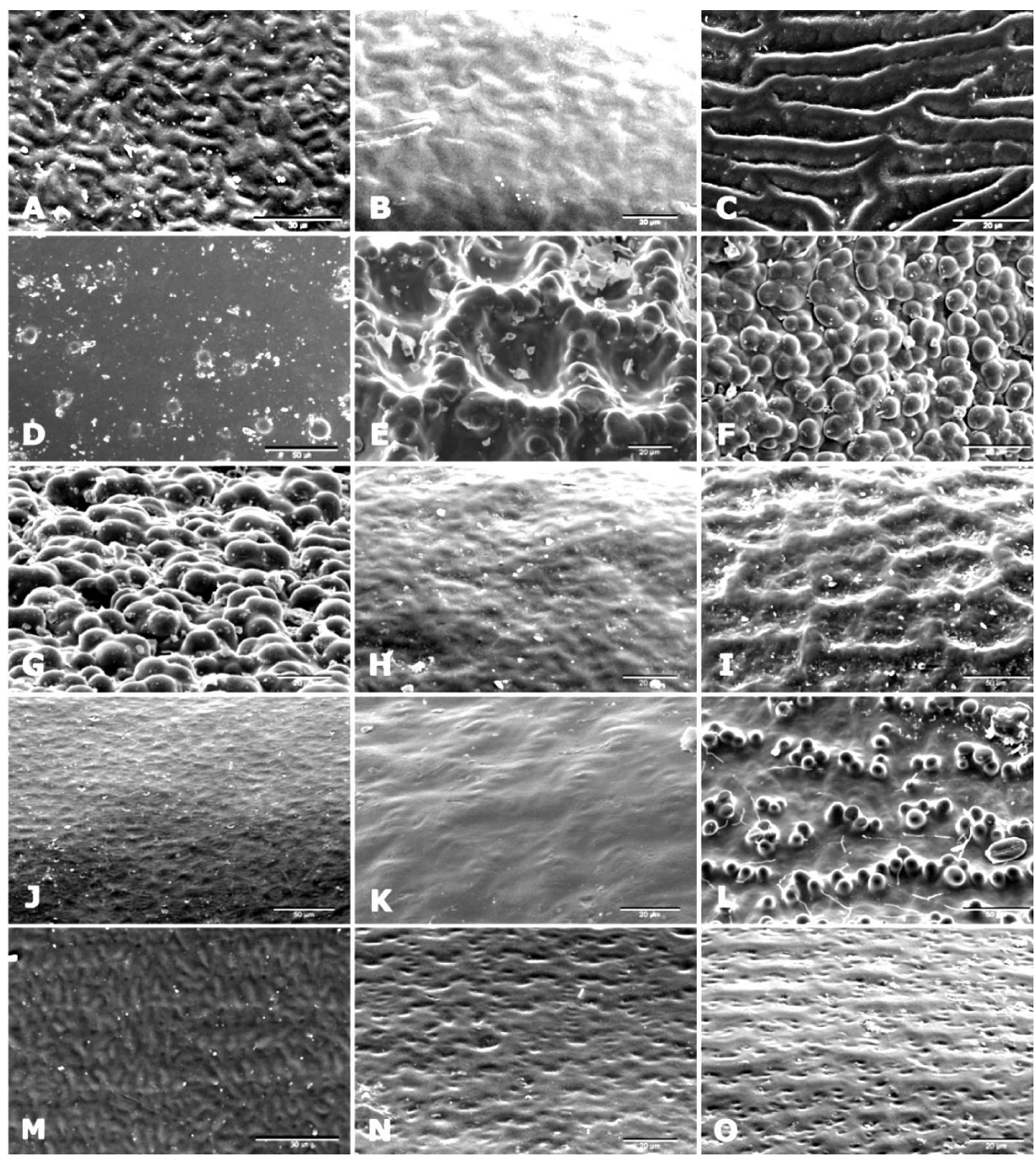

Fig. 3. The surface of achenes of Polygonaceae in Korea. A. Aconogonon alpinum (smooth); B. Bistorta manshuriensis (smooth); C. Fagopyrum esculentum (smooth); D. Fallopia convolvulus (papillae distributed irregularly); E. Persicaria nepalensis (sect. Cephalophilon; tubercles along the anticlinal cell walls); F. Persicaria maackiana (sect. Echinocaulon; tubercles distributed throughout entire pericarp); G. Persicaria sagittata (sect. Echinocaulon; tubercles distributed throughout entire pericarp); H. Persicaria nodosa (sect. Persicaria; smooth); I. Persicaria posumbu (sect. Persicaria; tubercles along the anticlinal cell walls); J. Persicaria pubescens (sect. Persicaria; shallow papillae); K. Fallopia japonica (shallow papillae); L. Polygonum aviculare (discontinued tubercles along the anticlinal cell walls); M. Rumex acetosa (smooth); N. Rumex crispus (small pits); O. Rumex obtusifolius (small pits). 
Tubercles or papillae were divided into two types based on their distribution patterns: Type (i), covered the entire achene (Fig. 3E \& F), and Type (ii), distributed along the anticlinal cell walls (Fig. 3E, I, J, K \& L). Type (i) tubercles were observed in three taxa of Persicaria, and they were densely or regularly distributed ( $P$. maackiana, P. sagittata, and $P$. senticosa; Fig. 3F \& G). Type (i) papillae were only observed in Fallopia convolvulus (Fig. 3D; Table 2), and were loosely and irregularly distributed compared to the tubercles. Type (ii) tubercles were observed in four taxa (Persicaria nepalensis, P. posumbu, Polygonum aviculare, and Rheum rhabarbarum; Fig. 3E, I, J \& L). Type (ii) tubercles of three taxa showed continuous distribution and were arranged along the anticlinal cell wall (Fig. 3E, I \& J), while those of Polygonum aviculare showed a discontinuous arrangement (Fig. 3L). Similarly, Type (ii) papillae were observed in three taxa of Persicaria ( $P$. lapathifolia var. lapathifolia, $P$. pubescens, and $P$. vulgaris; Fig. 3K), but these structures were represented by collapsed anticlinal cell walls (Ronse Decrane et al., 2000). Yurtseva (2001) suggested that the xerophytic taxa of Polygonum subsect. Polygonum usually had verrucae on the achene surface, while the taxa that inhabit wet environments did not. Although the functions of these verrucae are not clear, smooth and glossy surface increase water repellency and prevent fungal or pathogenic infection (Barthlott, 1981; Yurtseva, 2001). Thus, the verrucae could be related to water absorption. In the present study, some taxa without tubercles or papillae within other genera were distributed through wet valleys (e.g., Persicaria muricata); thus this is seemed to support the early suggestion. While there are also taxa which inhabit both environments (e.g., Persicaria senticosa also inhabit wet valleys; Li et al., 2003; Freedman and Reveal, 2005).

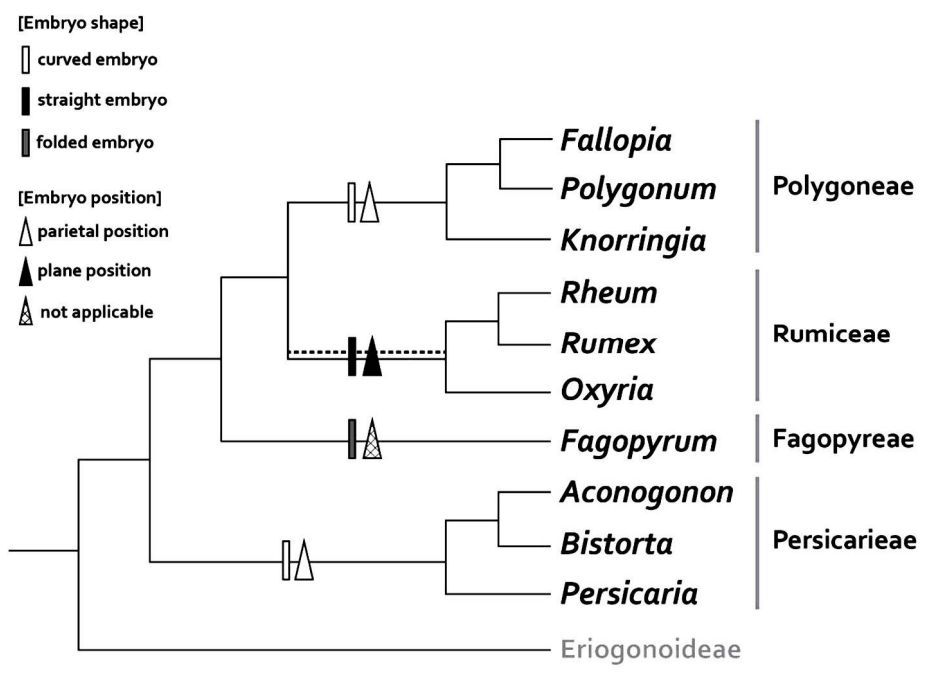

Fig. 4. Diagrams of embryo characters on most recent cladograms. Simplified phylogenetic tree is adopted from Schuster et al. (2015). Embryo shape was described as rectangular, and embryo position was described as triangular. The dotted line means that various type of embryo shape were observed in this group compared to those found in early studies (e.g., Freedman and Reveal, 2005; Sanchez et al., 2011).

Small pits were observed to be scattered on the surface of most Rumex taxa (R. acetosella, $R$. crispus, $R$. maritimus, $R$. obtusifolius, and $R$. patientia; Table 2; Fig. 3N \& O). According to a previous study, the small pits were also found in the Persicaria sect. Tovara (investigated taxa: $P$. neofiliformis and P. virginiana; Ronse Decrane et al., 2000); however, the Persicaria sect. Tovara (P. filiformis) used in this study had a smooth surface (Table 2). This difference in surface sculpture could be considered to be interspecies difference. 


\section{Taxonomic implication of achene morphology in Korean Polygonaceae}

The taxonomic position of Aconogonon has been controversial. The Aconogonon was usually acknowledged to be an independent genus although it was belonged to Polygonum s.l. in early studies (Hedberg, 1946; Haraldson, 1978; Freedman and Reveal, 2005). The sister group of the Koenigia with Aconogonon is Bistorta. In comparison with achene morphology, almost all characteristics, such as the shape, size, existence of beak, glossy, embryo and smooth surface, are similar between Aconogonon and Bistorta. The genus Koenigia in previous study had also same embryo type and smooth surface as in Aconogonon and Bistorta; however, the achene is distinguished from Aconogonon-Bistorta based on the lack of beak, glossiness and smaller size (cf., 1.10-1.84 ×1.79-1.02 mm; Ronse Decrane et al., 2000; Kong and Hong, in prep.).

Persicaria lapathifolia var. lapathifolia is complicated taxonomically, thus many taxa were treated as synonyms of this taxon (e.g., Freedman and Reveal, 2005; Chang et al., 2014). For example, $P$. lapathifolia var. salicifolia and $P$. nodosa, were treated as synonyms of $P$. lapathifolia var. lapathifolia (Freedman and Reveal, 2005; Chang et al., 2014), or only one of them was treated as synonym (Timson, 1963). Li et al. (2003) suggested that P. lapathifolia var. salicifolia was admitted independent variety of $P$. lapatifolia var. salicifolia. The achene morphological characteristics between $P$. lapathifolia var. salicifolia and $P$. nodosa appeared to be more similar rather than those between $P$. lapathifolia var. salicifolia and P. lapathifolia var. lapathifolia (Table 2). Thus, P. lapathifolia var. lapathifolia and P. lapathifolia var. salicifolia could be separated as independent variety from each other, although the taxonomic position of $P$. nodosa is still unclear based on its achene characteristics.

In conclusion, achene morphological characteristics are useful to recognize certain taxa to the species, generic, or tribal level. Of the studied characteristics, the surface micromorphology of achene or embryo characteristics are rather consistent at the generic or tribal level; for example, small pits were found in most Rumex taxa, and papillae were only found in Fallopia convolvulus. In addition, the comprehensive consideration of achene characteristics are more useful to identify at the species level; for example, dull, broadly ovoid, biconvex and achenes with tubercle walls are characteristics of $P$. nepalensis, and regularly tuberculate on the whole achene surface and straight embryo in the plane position (Type IV) are characteristics of Rumex acetosella. This achene morphological study could improve our understanding of Korean Polygonaceae. A comparative study with molecular phylogeny will further improve our understanding of systematic tendencies in these groups.

\section{Acknowledgements}

We are grateful to our colleagues (Dr. Moon, H.-K. and Oak, M.-K.) in the Laboratory of Plant Systematics at Kyung Hee University, and to our anonymous reviewers and editor. We are grateful to the herbarium keepers of $\mathrm{KH}$ for their permission to examine specimens and for the loan of materials. This research was supported by the project 'Studies on the Establishment of Seed Bank base for the Asian network' through the Korea National Arboretum [grant numbers 20150437 and 20170334], and partially supported by the Basic Science Research Program through the National Research Foundation of Korea (NRF) funded by the Ministry of Education, Sciences and Technology [grant number NRF-2018R1D1A1A09083715] to S.P. Hong.

\section{References}

Ball, H.W., Exell, A.W., Harding, J.P., Léonard, J., Lewis, J., Melderis, A. and Vander Veken, P. 1962. Systematics association committee for descriptive biological terminology. II. Terminology of simple symmetrical plane shapes (Chart 1). Taxon 11(5): 145-156. 
Barthlott, W. 1981. Epidermal and seed surface characters of plants: systematic applicability and some evolutionary aspects. Nordic J. Bot. 1(3): 345-355.

Brandbyge, J. 1993. Polygonaceae. In: Kubitzki, K. and Bittich, V. (Eds), The Families and Genera of Vascular Plants. Springer, Berlin, pp. 531-544.

Chang, C.S., Kim, H. and Chang, K.S. 2014. Provisional Checklist of Vascular Plants for the Korea (KPF) (Version 1.0). Designpost. Seoul, 561 pp.

Choi, B.K., Duretto, M.F. and Hong, S.P. 2012. Comparative seed morphology of Boronia and related genera (Boroniinae: Rutaceae) and its systematic implications. Nordic J. Bot. 30(2): 241-256.

Donoghue, M.J., Baldwin, B.G., Li, J. and Winkworth, R.C. 2004. Viburnum phylogeny based on chloroplast trnK intron and nuclear ribosomal ITS DNA sequences. Syst. Bot. 29(1): 188-198.

Freeman, C.C. and Reveal, J.L. 2005. Polygonaceae. In: Flora of North America Editorial Committee (Eds), Flora of North America, Vol. 5. New York: Oxford Univ. Press, pp. 479-601.

Haraldson, K. 1978. Anatomy and taxonomy in Polygonaceae subfam. Polygonoideae Meissn. emend. Jaretzky. Symb. Bot. Ups. 22(2): 1-95.

Hedberg, O. 1946. Pollen morphology in the genus Polygonum L. s. lat. and its taxonomical significance. Svensk Bot. Tidsk. 40: 371-404.

Hou, Y.T., Xu, C.M., Qu, C.Y., Ba, X.G., Lu, F.J. and Li, F.Z. 2007. A study on fruit morphology of Polygonum sect. Polygonum (Polygnaceae) from China. Acta Phytotaxon. Sin. 45(4): 523-537. [in Chinese with English summary]

Jacobs, B., Donoghue, M.J., Bouman, F., Huysmans, S., and Smets, E. 2008. Evolution and phylogenetic importance of endocarp and seed characters in Viburnum (Adoxaceae). Int. J. Plant Sci. 169(3): 409-431.

Jacobs, B., Bell, C. and Smets, E. 2010. Fruits and seeds of the Valeriana clade (Dipsacales): Diversity and evolution. Int. J. Plant Sci. 171(4): 421-434.

Kantachot, C. and Chantaranothai, P. 2011. Achene morphology of Polygonum s.l. (Polygonaceae) in Thailand. Tropic. Nat. Hist. 11(1): 21-28.

Kim, M.H., Kwak, M., Song, J., Lee, S.J., Yoo, M.J. and Park, C.W. 2001. Morphology of hairs, flowers, and achenes of Polygonum section Echinocaulon Meisn. (Polygonaceae). Korean J. Plant Taxon. 31(2): $143-$ 160. [in Korean with English summary]

Lamb Frye, A.S. and Kron, K.A. 2003. Phylogeny and character evolution in Polygonaceae. Syst. Bot. 28(2): 326-332.

Lee, T. 2003. Polygonaceae. In: Coloured Flora of Korea, Vol. I. Hyangmunsa, Seoul, pp. 245-279. [in Korean].

Lee, J.K., Kim, J.H., Lee, S.M., Park, S.H., Ali, M.A., Kim, J.K., Lee, C.Y. and Kim, G.R. 2010. Seeds of wild plants of Korea. <http://www.seedbank.re.kr/>. Korea Research Institute of Bioscience \& Biotechnology, Dajeon, Korea.

Li, A.J., Bao, B., Grabovskava-Borodina, A.E., Hong, S.P., McNeill, J., Mosyakin, S.L., Ohba, H. and Park, C.W. 2003. Polygonaceae. In: The Flora of China Editorial Committee (Eds), Flora of China, Vol. 5. Missouri Botanical Garden Press: Saint Louis, pp. 277-350.

Martin, A.C. 1946. The comparative internal morphology of seeds. Am. Midl. Nat. 36(3): 513-660.

Martin, A.C. 1954. Identifying Polygonum seeds. J. Wildlife Manag. 18(4): 514-520.

Nakayama, S., Inokuchi, M. and Minamitani, T. 2004. Seeds of wild plants in Japan. Tohoku University Press, Sendai. [in Japanese].

Navajas-Pérez, R., de la Herrán, R., López González, G., Jamilena, M., Lozano, R., Ruiz Rejón, C., Ruiz Rejón, M. and Garrido-Ramos, M.A. 2005. The evolution of reproductive systems and sex-determining mechanisms within Rumex (Polygonaceae) inferred from nuclear and chloroplastidial sequence data. Mol. Biol. Evol. 22: 1929-1939.

Park, C.W. and Hong, S.P. 2007. Polygonaceae Juss. In: Flora of Korea Editorial Committee (Eds), The Genera of Vascular Plants of Korea. Academy Publishing Co., Seoul, pp. 334-360.

Rechinger, K.H. 1937. The North American species of Rumex. (Vorarbeiten zu einer Monographie der Gattung Rumex 5.) Publ. Field Mus. Nat. Hist., Bot. Ser. 17: 1-150. 
Ronse Decraene, L.P. and Akeroyd, J.R. 1988. Generic limits in Polygonum and related genera (Polygonaceae) on the basis of floral characters. Bot. J. Linn. Soc. 98(4): 321-371.

Ronse Decraene, L.P., Hong, S.P. and Smets, E. 2000. Systematic significance of fruit morphology and anatomy in tribes Persicarieae and Polygoneae (Polygonaceae). Bot. J. Linn. Soc. 134(1-2): 301-337.

Sadeghian, S., Zarre, S. and Heubl, G. 2014. Systematic implication of seed micromorphology in Arenaria (Caryophyllaceae) and allied genera. Flora 209(9): 513-529.

Sanchez, A., Schuster, T.M. and Kron, K.A. 2009. A large-scale phylogeny of Polygonaceae based on molecular data. Int. J. Plant Sci. 170(8): 1044-1055.

Sanchez, A., Schuster, T.M., Burke, J.M. and Kron, K.A. 2011. Taxonomy of Polygonoideae (Polygonaceae): A new tribal classification. Taxon 60(1): 151-160.

Schuster, T.M., Reveal, J.L., Bayly, M.J. and Kron, K.A. 2015. An updated molecular phylogeny of Polygonoideae (Polygonaceae): Relationships of Oxygonum, Pteroxygonum, and Rumex, and a new circumscription of Koenigia. Taxon 64(6): 1188-1208.

Song, J.H., Kim, J.M., Oak, M.K. and Hong, S.P. 2015. Comparative seed morphology of the tribe Alsineae (Caryophyllaceae) in Korea and its taxonomic implications. Korean J. Pl. Taxon. 45(4): 369-379.

Timson, J. 1963. The taxonomy of Polygonum lapathifolium L., P. nodosum Pers, \& P. tomentosum Schrank. Watsonia 5: 386-395.

Thiers, B. 2018. [continuously updated] Index Herbariorum: A global directory of public herbaria and associated staff. <http://sweetgum.nybg.org/science/ih/>. New York Botanical Garden's Virtual Herbarium, Bronx, U.S.A.

van der Pijl, L. 1982. Principles of Dispersal in Higher Plants ( $2^{\text {nd }}$ ed.). Springer-Velag. Berlin. 162 pp.

Yurtseva, O.V. 2001. Ultrasculpture of achene surface in Polygonum section Polygonum (Polygonaceae) in Russia. Nord. J. Bot. 21(5): 513-528.

Zhu, L.T., Lu, F.J., Hou, Y.T. and Li, F.Z. 2007 Micro-morphology of leaf epidermis and its taxonomic significance of Polygonum section Cephalophilon in China. J. Wuhan Bot. Res. 25(2): 136-142. [in Chinese]. 